\title{
RELAÇÕES ENTRE OS ESTADOS UNIDOS E A AMÉRICA LATINA DURANTE A GUERRA DE SECESSÃO. MUDANÇA OPERADA EM 1861.
}

\author{
DEUSDA MAGALHÄES MOTA \\ do Departamento de História da Faculdade de Filo- \\ sofia, Letras e Ciências Humanas da Universidade de
}

São Paulo.

No período da Guerra Civil dos Estados Unidos, de 1861 a 1865, ocorreu a primeira grande mudança de atitude nas relações entre os paises da América Latina e aquela grande república. Essa mudança é melhor entendida se se conhecer alguns dos vários aspectos das condições de relacionamento que vigiam na época entre as repúblicas latinas e a América do Norte, e as próprias situações internas em que se encontrava a nação.

Em princípio, havia desconfiança geral e má vontade nas repúblicas latinas em relação aos Estados Unidos, principalmente nas naçōes do continente sul, antes do começo daquele conflito. E de fato, a política norte-americana caracterizava-se por ser agressiva e prepotente na sua política exterior, principalmente com as fracas repúblicas sul-americanas, nos anos que precederam à guerra civil. E era expansionista por execelência. Os Estados Unidos, na sua política exterior pretendiam impor a sua hegemonia sobre os paises latinos, como de fato impôs por muitos anos, sem demonstrar solidariedade operativa, compreensão e diálogo direto. Ao tempo empenhavam-se mais na disputa hegemônica com as potências européias, fosse na América, fosse no próprio continente europeu, e no mar.

A república norte-americana imperava soberana na ânsia de afirmar-se cada vez mais perante as potências européias. Com relação à América Latina, sua atitude era diferente. Nem por necessidade de sua própria defesa tomando-a como ponto de apôio, nem por interesse econômico levaram-na a trata-la com tato e consideração, ou interessar-se por um relacionamento melhor. Ela na verdade, não represen- 
tava ameaça militar, e nem os Estados Unidos estavam presos a ela por grandes interesses econômicos e mercantis que devessem ser preservados com zelo e os obrigassem a um trato cordial especial. Sob o ponto de vista estratégico, não constituia tão pouco, áreas geopolíticas de algum valor, como o são hoje. Até a década que precedeu à guerra civil, as relações comerciais entre os Estados Unidos e essas nações eram pequenas, quase insignificantes. A balança comercial da América Latina era muito modesta, registrava apenas $4 \%$ para as suas exportações e mais ou menos $9,7 \%$ para as importações.

Como as relaçōes entre as naçōes seguem geralmente a direção do interesse comercial ou do interesse geopolítico, a política dos Estados Unidos dirigia-se nessa época para os mais importantes mercados europeus. Foram pequenos os interesses políticos e comerciais tomados para com os paises latinos da América, e estes foram mesmo sempre tratados com quase nenhum cuidado. Até pelo contrário, as atitudes hostis eram bem evidentes e frequentes, fosse pelas constantes expedições "flibusteiras" no mar das Caraibas, fossem pelas declaraçōes pouco veladas que deixavam transparecer idéias políticas de expansão sobre o seu território. Para evidenciar essa tendência temos a guerra contra o México, demonstrando que o país do norte era uma séria ameaça à soberania das nacoões do sul. Todas as atitudes faladas, escritas e de ação da grande nação evidenciavam essa ameaça de que tanto se falava e temia.

Em 1856 realizou-se uma Conferência em Santiago do Chile, na qual os representantes desse país, os do Equador e os do Perú assinaram um tratado feito para promover laços mais fortes entre todas as repúblicas latinas contra os Estados Unidos. Esse tratado revelou o real sentimento de receio velado ou declarado reinante entre elas. Pode-se dizer que o mesmo sentimento existia em todas as outras co-irmãs, embora não tivessem participado dessa reunião primeira. Desde então, as repúblicas latinas da América deram forma mais evidente ao seu forte sentimento de indisfarçada reação contra os Estados Unidos. O presidente James Buchanan foi eleito em 1855. Era do Partido Democrático e nascido em Pensilvânia. Esse partido político ao qual pertencia era e é ainda tiđo como o mais liberal, procurando governar pelas concessões sociais e econômicas, por isso mesmo é considerado esquerdizante. Mesmo com essas características a sua administração de maneira alguma diminuiu essa suispeita e tensão reinantes. O período de seu mandato, como o período anterior, representou a fase mais agitada da política interna dos Estados Unidos, entremeada por terrivel crise econômica, política e social. Era a época da grande preocupação pela pacirícação do Kansas, que girava justamente em torno da extensão ou não da escravatura naquele território, bem como em torno da definição, que se esperava fosse definitiva, do estabelecimento dos direitos do ne- 
gro escravo do sul quando se transferisse com o seu dono para os territórios não escravagistas. Transferindo-se com o seu dono para os Estados não escravagistas estaria ele livre ou continuaria escravó como se estivesse no seu próprio Estado escravagista? Como se vê, somente esse problema encerrava interesse e conflito de ordem econômica, política e social de relevância para a naçāo. Foi o período de granđes lutas e ressentimentos políticos internos, remanescentes do ano eleitoral que antecedeu, das definições dos grandes problemas escravagistas nos territórios novos e das tendências de libertação dos escravos. O país se debatia pois, numa crise interna das mais graves.

Foi no decorrer dessa crise política, econômica e social interna que se esboçaram as primeiras reações da América Latina para com os Estados Unidos. Essa crise era tão grave e profunda, que levou à guerra civil de 1861. Debatendo-se em tão grave situação interna desde há muitos anos, não houve tempo disponivel e nem condições, ou mesmo disposição da norma política interna adotada, que permitissem atenção especial à política externa para com a América Latina. Nem nos parece estivesse aquele país desejoso de te-lo feito.

Em 1861 já havia passado o período presidencial de James Buchanan. Abrahão Lincoln o substituira, e como tal, tornou-se herdeiro de todos os problemas que viriam à tona, o mais grave dos quais o da escravidão, e consequentemente a rebeliẫo dos sulinos, e finalmente, a guerra de secessão de 1861. Abrahão Lincoln estava bem afinado com os problemas do país, como militante ativo da sua política. Agora, era responsavel pelas soluções requeridas. A guerra civil colheu o recem-instalado governo de Lincoln desprevenido, em condições bem precárias. O país estava combalido, dividido profundamente em dissensões internas e despreparado para enfrentar qualquer situação conturbada. O presidente Lincoln, instalado no governo do país, não tivera tempo de por a casa em ordem, e estava desprevenido interna e externamente, quando a tão grave crise irrompeu. O país estava praticamente seccionado profundamente em dois campos beligerantes - $\mathbf{o}$ norte e o sul. As facções se degladiariam ferozmente por longos anos como se não fossem irmãos.

Entre as muitas medidas de ordem imediata a que o Presidente se lançara para fortalecer a causa da União, e fazer voltar à razāo os sulistas rebeldes estava o que dizia respeito à reformulação da política externa. E desta, a revisão do relacionamento com a América Latina era muito importante. Era urgente estabelecer o quanto antes uma política de aproximação e de entendimento com essas repúblicas. Era urgente anunciar-lhes a mudança da política externa que os Estados Unidos estavam dispostos a levarem avante para com elas. Dizer-lhes que se abria uma nova fase histórica de relacionamento entre as nações 
da América. E de fato, os diplomatas de Lincoln procuraram desfazer as lembranças amargas que os latinos da América guardavam das atitudes agressivas que sempre houve para com eles. Argumentaram junto a essas nações, que os males e equívocos pasșados haviam sido engendrados pelos sulistas da Confederação, agora rebeldes declarados em franca luta separatista, e difundido a notícia para efeito de propaganda contra a causa dos legalistas da União. As relaçōes estrangeiras tornaram-se o ponto vital para que a União conduzisse bem a repressão à rebeldia interna, contando com o apôio moral dessas repúblicas. Era importante estratégica e psicologicamente que fosse evitado o reconhecimento possivel da Confederação sulista rebelde por algum país, fosse da América ou fosse da Europa. E isso poderia acontecer como atitude de vingança de alguma nação ressentida.

Até então, a América Latina tinha sido tratada de modo geral com pouca atenção pelos Estados Unidos. Agora, o bom relacionamento com os paises do sul tornou-se ponto importante no novo quadro político interno que se punha no país, tanto para Washington quanto para os Confederados. Era necessário que o Ministro de Estado Seward assegurasse para o governo legal a simpatia dos paises sul-americanos e os convencesse de que o seu bem estar, a sua segurança e os seus interesses futuros estavam com a causa da União Federal e não com a causa dos Confederados. Por sua vez, os sulistas rebeldes tambem viam as boas possibilidades para si, em estabelecendo um bom relacionamento com esses paises, e deveriam promover a política de estreitamento de relações, e tanto quanto possivel o reconhecimento por eles, de sua situação de direito como beligerantes.

A nova política de estreitamento de relações exteriores foi imediatamente iniciada pelo governo da União. Na sua mensagem ao Congresso de abril de 1861 , pediu verba para as despesas de agentes diplomáticos que deveriam se instalar nos paises sul ameircanos. Foi a primeira grande decisão positiva em prol das repúblicas americanas do sul. O presidente esperava para a boa receptividade de seus enviados e a boa aceitação de suas pretensões, que os latino-americanos, individualistas e defensores da independência de seu próprio país, vissem na luta dos Confederados um exemplo perigoso de rebeldia facil de ser imitado e implantado nos seus próprios paises contra os governos constituidos. E de fato, esses paises latinos da América tinham muitos problemas internos de ordem política, social e econômica, como de resto os têm até hoje, para serem resolvidos. Entre eles, os conflitos nacionalistas latentes nas massas do povo, que poderiam irromper nos diversos pontos do continente, pelo exemplo norte-americano, quando se apresentasse a primeira oportunidade. Esses paises eram e são ainda hoje muito propensos à instalação de regimens de oligarquias 
aristocráticas, que lutam permanentemente pela retomada do governo, e são propensas ao aparecimento de indivíduos que se encaminham pela via natural do carisma e do populismo ao caudilhismo e às ditaduras. E que esses paises têm o tronco inferior da pirâmide social representado por $70 / 80 \%$ da massa analfabeta do povo, sem visão da perspectiva política global do país pobre como são todos os da América Latina. Essa massa apoia facilmente candidatos aventureiros da oposição que se apresentam com programas de reformas milagrosas, assumindo atitudes populistas e carismáticas, que se apresentam sempre com promessas de realizarem transformações que sabem impossíveis a curto prazo. Eleitos pelo apôio dessa massa ignorante e com facil influência populista, não podendo realizar o impossivel que prometeram, ou renunciam ao mandato jogando o país no caos, ou fazem calar os reclamantes pela força das armas, transformando-se de populista ou carismáticos em ditadores ou caudilhos. Eis como nascem esses personagens, que constituem fenômeno tão frequente da América Latina. Como caudilhos ou ditadores dominam o país pela força, e subjugam essa massa que o elegeu, e a todos quantos a eles se opuzerem. E nessas circunstâncias de uso da psicologia da massa ignorante, que poderia nascer um movimento de hostilidade às relações com os Estados Unidos, agitando a bandeira do falso nacionalismo por algum aventureiro desses paises.

Não se sabe como os Confederados se comportaram nessa política externa de aproximação. Não se tem notícia se promoveram ou não essa política de simpatia e aproximação junto às nações latino-americanas para a sua causa de uma maneira sistemática, efetiva e prática, ou se promoveram condiçöes de mante-las em simples neutralidade ao movimento. O fato é que, por alguma razão estranha, apenas ao México foi mandada a única missão dos Confederados que se tem notícia, a fim de atrai-lo à causa sulista. Nenhum outro representante oficial dos Confederados foi enviado aos demais paises da América Latina. Nem mesmo algum pedido oficial de reconhecimento dos Confederados como beligerantes foi feito a qualquer embaixada sul-americana. Se isso não se deu, pode-se atribuir mais à indecisão de ação dos rebeldes, indecisão tão frequente em Richmond, capital dos Confederados e sede de comando do movimento; ou pode-se atribuir à mudança nos primeiros planos que haviam estabelecido para a luta. O fato é que não houve diligências dos Confederados nesse setor estrangeiro. Constitui ainda hoje um mistério a ausência diplomática dos Confederados junto aos paises sul-americanos. 
O trabalho dos representantes diplomáticos de Washington junto aos governos dos paises latinos da América.

Os homens que representavam o governo de Lincoln eram geralmente bem qualificados e experientes: Levaram avante e com êxito o trabalho planejado no campo diplomático, junto às nações latinas da América, em prol da sua causa.

Nessa missão destacaram-se os diplomatas $\mathrm{N}$. Nelson no Chile, Cristopher Robinson no Perú, e Roberto C. Kirk na Argentina. Estavam todos bem preparados para a sua tarefa. Os outros representantes diplomáticos dos Estados Unidos, como Henry T. Brow na Venezuela e D. T. Carter na Bolívia eram políticos acostumados à atividade diplomática, $\mathrm{e}$ nenhuma dúvida deixariam do êxito que alcançariam na sua tarefa. O mais brilhante, entretanto, foi o General J. Watson Webb, que veio servir no Brasil. Sua principal característica era a seriedade excessiva em que se atinha. Era muito prolixo nas suas extensas notas diplomáticas. Para ele, essas notas minunciosas eram o melhor estilo jurídico da representação diplomática.

Esses diplomatas do governo legal dos Estados Unidos promoveram diretamente uma campanha político-diplomática para difundir a idéia da necessidade de união das nações latino-americanas entre elas mesmas. O objetivo era, ao final, fazerem-nas sentir a vantagem de os Estados Unidos permanecerem coesos em torno do governo federal legal, e não seccionado em duas nações, como era o quadro que se apresentava no decorrer da guerra civil. Esses diplomatas mandados de Washington procuraram estabelecer uma comunidade de interesses cntre os Estados Unidos como nação integrada e os paises sul-americanos. Iniciou-se um grande movimento ou campanha para promover e despertar a boa vontade e a conscientização das nações sul-americanas pelo apôio à causa da União.

Os dignatátios diplomáticos trouxeram um esquema único de trabalho. Para catalizar as simpatias para o seu governo, apresentaram-se com três teses de argumento:

a). - abolição da escravidão;

b). - preservação dos princípios democráticos;

c). - proteção contra a intervenção estrangeira.

Essas três teses apresentadas tiveram força bastante para promover grande efeito psicológico nas nações da América Latina e alcançar os objetivos visados - obter o apôio moral dessas nações em torno do governo legal dos Estados Unidos contra os Confederados.

Havia muito tempo que a escravidão tinha sido abolida do continente sul, exceto no Brasil, o que se daria somente em 1888. As dele- 
gações diplomáticas do governo dos Estados Unidos fizeram saber aos paises latinos que a guerra civil visava manter a escravidão, e portanto, era contrária aos interesses dos povos livres. Essa tese obteve logo a adesão do grupo liberal anti-escravagista das nações sul-americanas, inclusive o do Brasil. Fizeram saber mais que a guerra civil era um esforço de um grupo rebelde para destituir as autoridades legalmente constituidas. Isto significava que se a União perdesse a guerra, os governos legitimamente constituidos nos paises sul-americanos não teriam garantia de estabilidade, pois o exemplo dado pela grande nação norte-americana facilmente seria imitado no sul. Portanto, era necessário manter o princípio da legitimidade dos governos eleitos, lá como aqui. Esse argumento causou profundo efeito naqueles que conheciam bem a tragédia e as dificuldades de uma guerra interna. Com medo de que, pelo exemplo da guerra civil americana se ela tivesse êxito, encorajasse conflitos internos e pudesse dar início aos perigos das guerras civis ou revoluçöes internas, nos paises da América Latina, estes começaram a desejar o sucesso da facção do governo legal e a ela se perfilharem.

A terceira tese, a da proteção contra a intervenção estrangeira foi finalmente o mais forte argumento usado pelos diplomatas de Washington. Argumentaram que a vitória do Sul abriria caminho para intervenção estrangeira na América Latina, fosse da Europa ou não... Era na verdade uma advertência velada da possivel interferência da própria América do Norte, e obviamente da Europa nesses paises. Talvez advertissem de que a América seria o campo de guerra entre as potências européias e os Estados Unidos, pela disputa hegemônica da América Latina.

Os episódios das agressões dos Estados Unidos, de que as naçōes da América bem se lembravam, como as referidas expedições dos "ffibusteiros" dos anos passados nas Caraibas, bem como a maior parte das doutrinas expansionistas apregoadas e conhecidas, tinham sido inspiradas nos estados sulistas rebeldes, como faziam crer. Talvez fossem na verdade, advertências das futuras relações tensas que se seguiriam, caso a União não fosse a vencedora. Entretanto, os diplomatas do Norte procuraram desfazer essas lembranças atribuindo-as aos sulistas da Confederação, que as inspiraram e difundiram para efeito de propaganda contra a causa dos legalistas da Uniāo.

Essas teses foram sistematicamente expostas e divulgadas pelos dignatários diplomáticos oficiais de Washington, e não encontraram delegados dos Confederados para nega-las no todo ou em parte. Portanto, tais argumentos permaneceram como verdades sem contestação, e aquelas dúvidas que causaram ressentimentos e desconfianças foram dissipadas. 
A tese que causou profunda impressão na opiniāo pública dos paises latinos foi a de que os Estados Unidos coesos de norte a sul, em torno de um governo legal, único e forte, eram um baluarte seguro contra a intervenção da Europa em qualquer tentativa que se puzesse em relação ao hemisfério ocidental. . Era conclusivo que, se os Estados Unidos fossem uma única nação poderosa, tais interferências estrangeiras, como a que ocorreu no México em 1861 pela intervenção conjunta da Grã-Bretanha, França e Espanha contra Juarez, jamais teria ocorrido. Este argumento produziu, pois, uma repercussão favoravel mesmo nas áreas em que as questões anti-escravagistas interessavam apenas a uma pequena parte da população.

Como consequência, as várias repúblicas latinas foram tocadas pela nova política norte-americana em relação a elas. A partir de então, adotaram a opinião da necessidade de promoverem a união entre elas, em primeiro lugar, e depois, a união de todas em torno dos Estados Unidos não divididos, para desfrutarem de uma assistência mútua. A política externa das nações sul-americanas mudou sensivelmente. E o comportamento dos Estados Unidos, passada essa crise em que se viu a braços teria mudado?

O fato é que, essa data é um marco na direção histórica da América Latina, que se desprendeu mais da influência europeia e voltou-se mais para o hemisfério ocidental. A partir desse momento deixou a América Latina de ser constituida por nações isoladas, fracas, entregues a sí mesmas, sem poderem se organizar, para se tornarem um poder visivel e mais representativo na ordem das nações $\left({ }^{*}\right)$. 1941 .

(*). - Ferris (Natan), in The Hispanic History Review. Vol. XXI, n 1. 